law, ${ }^{28}$ and this rule applies, it seems, to wills disposing of real property. A will relating to French real property may be executed also, accordand to Aubry \& Rau, ${ }^{28}$ in conformity with French law, that is in the holographic form of Article 970 of the French Civil Code.

It remains to be seen whether the French courts in the development of the rule locus regit actum in its application to wills will restrict the parties to a choice between the law of the place of execution and their national law, or whether they will allow them to execute them with reference to the law of their domicil, and, if the will relates to land, with reference to the law of the situs. Another interesting question will be whether, for the sole purpose of sustaining wills, they will extend the application of the renvoi doctrine to the formal requirements of wills.

E. G. L.

FREEDOM OF SPEECH-A NOTE ON PROFESSOR CORWIN'S ARTICLE

As was to be expected, Professor Corwin, in his article appearing earlier in this number of the JouRNAL ${ }^{1}$ upon freedom of speech and press, accomplishes the difficult task of illuminating further a subject which has already been the occasion for much able discussion. Nevertheless, the very diversity of inferences which have been drawn by competent writers from the historical background against which stands the First Amendment warns us that contemporary construction gives no final answer to the problems we have to solve. Thus, from the well-known fact that opposition to the Sedition Act of $x 797$ was in part at least founded on doctrines of states' rights, Professor Corwin would apparently draw the inference that nationalists should uphold a broad view as to the power of Congress over speech and the press. But Mr. Hart has shown clearly the general consensus of opinion of all parties at the time of the adoption of the Constitution that neither by it nor by the First Amendment did Congress possess any general power over these subjects. ${ }^{2}$ Hence the inference is logically one of lack of power in Congress, and in fact its only powers in this regard are such as may be considered fairly necessary to carry out the grants of other powers to it. ${ }^{3}$ We must therefore always keep in mind that our problem is the application of the constitutional provisions to

\footnotetext{
${ }^{23}$ App. Paris, August 5, 1886 (I887) Clunet, 621 ; Dec. 23, I909 (Igro) Clunet, 604

${ }^{20}$ Io Aubry \& Rau, op. cit., 599.

${ }^{1}$ Freedom of Speech and Press Under the First Amendment: a Résumé (1920) 30 Yale Law Journal, 48. Other discussions are there cited.

${ }^{3}$ Hart, Power of Government over Speech and Press (1920) 29 YAle LAw JoURNAL, 4ID.

${ }^{3}$ Ibid. This, of course, follows from the fact that the powers of Congress are only those expressly or impliedly granted in the Constitution. Here there is no express grant.
} 
present-day situations. Surely Professor Corwin cannot justly tax liberal constructionists with inconsistency in asking that the restrictions of the First Amendment, too, shall not receive a construction that will reduce them to nothing.

Now it should be noted that the cases under the present wartime Espionage and Sedition Acts have raised questions of great importance which are wider than the limited query as to the power of Congress. These concern, among other things, the conduct of public prosecutors, of judge, and of jury. In fact, in the important series of cases which split the United States Supreme Court at its last term, the vital question in each case was not that of the constitutionality of the law, but whether the trial court had erred in holding that the prosecutor had made sufficient case to go to the jury. ${ }^{4}$ The constitutional question was only indirectly involved, calling simply for a construction of the law which would carry out the policy and comply with the restrictions, of the First Amendment. This, in the view of the dissenting judges, required a directed verdict for the defendants, since "a present danger of immediate evil or an [actual] intent to bring it about was not shown." 5 The majority have stated no limitation of this kind, but have so far taken the view that proof of the utterance of any language having a tendency to produce the evils forbidden by the statute makes a jury question. If this view is followed logically, it is difficult to see why conviction could not be sustained on proof of practically any agitation for the change of existing laws, since such agitation may surely have a possible tendency to induce violations of such laws. And if a conviction may be sustained, the whole benefit of the constitutional restriction is lost, for if it is to fulfill any other purpose than that of an indefinite moral admonition, it must operate to protect the individual from a jury which may under unusual conditions, such as the stress of war emotions, be predisposed against him.

To those of us who believe that at least the limitations set by the minority, unsatisfactory and indefinite as the $y$ are, must be strictly adhered to, both on general principle and because of the Constitution, there seem, among others, two especially strong grounds for our belief, one from the standpoint of the individual and one from the standpoint of the community. From the point of view of the individual who appeals to the First Amendment for protection it appears that the test of tendency only has given to prosecutors and courts the opportunity, availed of under a misguided view of patriotism, literally to pursue "poor and puny anonymities" in a way nothing short of disgraceful to the mind of one trained in a law that accords

\footnotetext{
-Abrams v. United States (I9r9) 250 U. S. 616, 40 Sup. Ct. r7; Pierce v. United . States (1920, U. S.) 40 Sup. Ct. 205 ; Schaefer v. United States (Ig20. U. S.) 40 Sup. Ct. 259.

${ }^{3}$ See (1920) 29 Yale Law Journas, 337, 677.
} 
the vilest wretch opportunity to show on a fair trial the innocence presumed in his favor until proven guilty. Examples of this kind have been collected in law review notes, ${ }^{6}$ and Professor Chafee has shown in some detail the attitude of the trial court in the Abrams case. ${ }^{7}$ In enforcing such a law, which clearly will reach the fool more often than the secret and clever intriguer, it is hard under the circumstances to expect impartial juries. Experience has shown that the accused may not even be sure of an impartial court.

But even more important than the fate of the few is the effect upon the many. The only hope of success for a government of and by the people is that the people should act under the spur of beliefs formed without compulsion and as a result of arguments tested by their power to get themselves "accepted in the market." Two of the most admirable qualities of the ordinary citizen are his patriotism and his respect for law. If an administration may brand views opposed to its own as criminal-and, by sentences extraordinarily long in comparison with all but the most heinous crimes, as dangerously criminal-its views need less intrinsic power to compete with others for the support of such citizen. The Abrams case furnishes an excellent example. The thought which Abrams and his associates so intemperately expressed was that the United States should not interfere with Soviet Russia. Subsequent events have shown that the Administration's course in Russia has been at least of debatable wisdom. But at the time when that public opinion was forming which either tolerated or actively supported that course, the Administration had the benefit of the exploitation by the press in news articles and editorials of a conviction and sentence of twenty years' imprisonment

\footnotetext{
- (Igig) 29 Yale Law Journal, I07; (Ig20) 33 Harv. L. Rev. 956. An example is that of the trial in New York of the Russellites-members of a religious order founded in 1870 and opposed inter alia to war-where the trial judge in the presence of the jury committed a witness for the defense to jail for contempt of court for testifying that he had never seen a defendant write and could not testify as to his signature, when the court thought he really could. Conviction was followed by a sentence of twenty years' imprisonment upon seven of the defendants and of ten years upon the other defendant, the judge's scathing comments being prominently displayed in the press. The defendants were refused admittance to bail pending appeal and were sent to Atlanta. Some time thereafter the Circuit Courr of Appeals directed that they be admitted to bail and still later ordered a new trial because of the possible prejudice resulting from the contempt proceedings. Rutherford iv. United States (I920, C. C. A. 2nd) 258 Fed. 855. The witness who was jailed had previously been ordered released by the United States Supreme Court after ten months' confinement. Ex parte Hudgings (1919) 249 U. S. 378, 39 Sup. Ct. 337. Cf. (1919) Yale LAw JournaI, 826. Thereafter the prosecutions were dropped.

'(I920). 33 HARv. L. REv. 747. Cf. Schaefer.v. United States, supra, where the fifth count, one of the counts upon which conviction was had, apparently rests entirely upon a mistranslation in the indictment of a newspaper item originally appearing in German. See Comments (Ig20) 29 Yale Law Jouranal, 677.
} 
given an opponent of its views. The creation of such an opportunity for the perversion of public opinion is too high a price to pay for anything but the prevention of "a clear and imminent danger" to the country. Perhaps this is not our most pressing danger, and yet it is hard to see how in a democracy there can be a much more vital one than that of such perversion of public opinion. Surely we have had enough of views promulgated by the most high, to be religiously accepted by all his followers.

C. E. C.

\section{CONFLICT OF LAWS IN WORKMEN'S COMPENSATION}

During the last seven years the subject of the conflict of laws under workmen's compensation acts has witnessed a decided trend of authority away from the strictly territorial theory of the legislation and in favor of that conception of the statute which regards it as a legislative standardization of certain master and servant contracts and therefore essentially a rule of contract law, applicable to all contracts otherwise governed by the law of the enacting state. In one respect, however, the divergent lines of authorities present a significant contrast. The territorial rule has been adopted in four jurisdictions and applied in seven cases, ${ }^{1}$ every one of which was a case of an extraterritorial injury under a local contract, involving therefore a renunciation of jurisdiction which would have been asserted under the contract theory. The latter, on the other hand, where accepted, has in every instance been established in cases involving a local contract of employment and an injury occurring outside the state. ${ }^{2}$ Where the converse case of a local injury under a foreign

${ }^{2}$ Hicks v. Maxton (Ig07) I24 L. T. Jour. I35; Tomalin v. S. Pearson \& Son [1909] 2 K. B. 6I ; Schwartz v. India Rubber etc. Co. [1912] 2 K. B. 299; Gould's Case (1913) 215 Mass. 480, I0z N. E. 693; North Alaska Salmon Co. v. Pillsbury (I9I6) I74 Calif. I, I62 Pac. 93; Kruse v. Pillsbury (19I7) I74 Calif. 222, 162 Pac. 891; Union Bridge \& Construction Co. v. Industrial Commission (Igrg) 287 Ill. 396, I22 N. E. 609. See also Keyes Davis Co. v. Allerdyce (April, r913) Mich. I. A. B.

${ }^{2}$ Kennerson v. Thames Towboat Co. (I915) 89 Conn. 367, 94 Atl. 372; Grinnell v. Wilkinson (1916) 39 R. I. 447, 98 Atl. 372; Roursaville v. Central $R$. Co. (I915) 87 N. J. L. 37I, 94 Ati. 392; Post v. Burger (Ig16) 216 N. Y. 544, III N. E. 35I; Gooding v. Ott (19I6) 77 W. Va. 487,87 S. E. 862 ; Foughty v. Ott (1917) 80 W. Va. 88, 92 S. E. I43; Jenkins v. Hogan \& Sons (1917) I77 App. Div. 36, 163 N. Y. Supp. 707 ; Gilbert v. Des Lauriers Columm Mould Co. (1917) 180 App. Div. 59, 167 N. Y. Supp. 274; Hagenback v. Leppert (1917, Ind. App.) II7 N. E. 531; State ex rel. Chambers v. District Ct. (I9I8) I39 Minn. 205, 166 N. W. I85; State ex rel. Maryland Casualty Co. v. District Ct. (I918) I40 Minn. 427, I68 N. W. I77; Industrial Commission v. Barene (1919) I07 Misc. 486, 177 N. Y. Supp. 689; Holmes v. Communipaze Steel Co. (I919) I86 App. Div. 645, I74 N. Y. Supp. 772; Industrial Commission v. Aetna Life Ins. Co. (I918, Colo.) I74 Pac. 589; Anderson v. Miller Scrap Iron Co. (1919) 169 Wis. 106, 170 N. W. 275 ; Pierce v. Bekins Van \& Storage Co. (Igrg, Iowa) I72 N. W. I9I. 